\title{
WITH WALT WHITMAN IN CAMDEN: A PROGRESS REPORT AND A SUPPLEMENT
}

\author{
Judith BASSAT
}

I should say, the thing to have is the truth: not to be satisfied even with the spirit of the truth, but to demand the fact itself: the divine, unaided, uncircumlocuted, unmanipulated fact, however bare, however it forbids: only in adherence to this is the safety of history.

Walt Whitman, September 23, 1890

"But that is what history is made up of: reports of reports, at second, third, fourth, removes: I suppose when I am gone there will be all sorts of stories set afloat by all sorts of liars." Then W. regarded me affectionately: laid his hand on my arm: "And that's where you'll come in, Horace-to set the crooked straight: that'll be your time: you'll jump into the breach then."

With Walt Whitman in Camden (4:457-458)

As WhitMAN SCHOLARS KNOW, the most important source of material on Whitman's later days is With Walt Whitman in Camden, the six-volume transcription of conversations between Walt Whitman and Horace Traubel, covering the period from March 28, 1888, to July 6, 1890 . Between 1888 and the day of Whitman's death in 1892, Traubel visited Whitman daily (three times daily during his final illness) and took notes in a "modified longhand." When he returned home from each visit, he wrote up his notes immediately in order to preserve the original spontaneity of the conversation. His intention was to publish the notes exactly as he had written them, in the form of a continuous narrative, without interpretation or editing, so as to provide a completely truthful biography of the poet. Whitman was aware of his project and cooperated by giving him numerous letters, photographs, and articles for his "Whitman gallery."

During his lifetime Traubel managed to bring out only three volumes (covering visits from March 28, 1888 through January 20, 1889), published in 1906, 1908, and 1914 by the Century Company (and reprinted in 1961 by Rowman and Littlefield). After his death the work was taken up by a series of editors. In 1953, the fourth volume was published, edited by Sculley Bradley and ending at April 7, 1889. Traubel's daughter Gertrude edited the fifth volume (April 8, 1889 to September 14, 1889), which was published in 1964. Finally the sixth volume, which had been substantially prepared by Gertrude (who died before it could be published), was edited by William White and ap- 
peared in 1982. It comprises conversations from September 15, 1889 to July 6, 1890. These last three volumes were all published by the Southern Illinois University Press. After the publication of the sixth volume the work was discontinued. Thus the last two years of conversations, from July 7, 1890 to March 26, 1892, the day of Whitman's death, have not yet been published; they exist only in the form of Traubel's original notes in the Charles E. Feinberg collection at the Library of Congress. So, although Whitman himself repeatedly expressed the desire to have the whole story told, one hundred years after Traubel began his great project, it still remains unfinished.

Realizing the importance of this work, the Fellowship of Friends, a non-profit California-based organization that uses the arts and culture as a means of spiritual refinement, undertook to complete the project. An editorial team, made up of Jeanne Chapman, Robert McIsaac, and myself-each of us with extensive editorial experience and a lifelong interest in Whitman-was formed for this purpose. We aim to publish the remaining volumes of the series by the centennial of Whitman's death in 1992.

Working with the original source material, we are well advanced in our transcription and editing of the remaining conversations and relevant correspondence (not an easy task, as a glance at Traubel's notes will show; see the fasimile page accompanying this article). In doing so, we have followed the editorial style established by Traubel in the first three volumes and continued by later editors. In his introduction to volume one, Horace Traubel states: "My story is left as it was originally written. I have made no attempt to improve it. I have taken nothing off and put nothing on." We have tried to remain true to this spirit, and have thus "edited" as little as possible, concentrating our efforts on preparing a meticulously accurate transcription of Traubel's notes, correcting only the obvious slips and repetitions, and checking the references.

In these volumes we intend to include the great majority of the correspondence referred to in Horace's notes, eliminating only those letters of virtually no interest. We also intend to add appendices, which would include supplementary material relevant to the volume, as for example, in volume 7, Robert G. Ingersoll's magnificent address for the Whitman Benefit held in October 1890.

Although we have not yet completed our transcription work, the remaining unpublished material will most likely add three volumes to the first six of the series. The material for the first new volume, including letters and photographs, is now ready for publication. The material for the second volume will be complete by spring 1991, and that for the third by spring 1992 .

At this stage the only element missing in our plan to complete the series for the centennial of Whitman's death is a publisher. Perhaps the 
readers of the Walt Whitman Quarterly Review can assist us in this. As the manuscript will be entirely edited and inserted on computer disk, a considerable amount of the publisher's usual labor is already completed. Naturally we hope to maintain the style of printing and binding used in the earlier volumes.

There is no need to convince the readers of this journal of the immense significance of the project. It is a work of discovery, coming direct from Traubel to us. As in the previous volumes, the conversations are brimming with insight, humor, and interest. Whitman returns to his favorite themes-Lincoln, Emerson, O'Connor, the vicissitudes of Leaves of Grass - and touches upon new ones, such as Robert Ingersoll and Christianity. As the months pass, Whitman's friendship with and dependence on Traubel grows. Perhaps most moving of all is the account of his hourly struggle with pain, old age, and death.

We are working our way through the material chronologically, but we did jump ahead to transcribe Whitman's last few months. What emerges is a strikingly poignant document, perhaps unique in literary history. Although he was overcome with grief, Traubel never lost sight of his original aim to faithfully record everything Whitman said, down to his very last words, loving as always, choked out on his deathbed.

Although the work is most interesting in its entirety, we present here a sampling of several days of conversations:

\section{Friday, Fuly 25, 1890}

5:30 P.M. W. in his room. Took him up the two local papers, thrown in hallway by newsman. "The Post seems to be doing some good printing for itself nowadays." Was reading Kennedy's piece in Conservator again as I entered. Asked me about city life-curious for incidents. I told him of a man with torn foot, thrown under a wagon. When I saw him, bleeding, reclining, waiting for patrol wagon, which had been signalled for. W. questioned me-the wound, how the man seemed to take it-was he pale? did he tremble? conscious? and all that, and "the curious, inquiring, yet hurrying crowd" took him "back into war times, to hospital scenes." Returned me Harper's Weekly, which he had laid out on the bed. I left Bazar with him. "We ought to know what is being done, even when we find it is not done our way."

While we sat talking the bell rang and shortly Warren came in, handing W. a letter and paper left by the mail-man. W. laid the paper aside and opened the letter. He had put on his glasses. I noticed the change in his color. Noticed, too, the familiar hand (his brother-in-law's, Heyde's) as he held the letter up. As if oblivious to my presence, W. suddenly shook the letter fiercely with clenched right hand, exclaiming passionately, "Goddam your soul to hell! Damn you! Damn you!" looking at the letter for a long space-breaking forth again: "Yes! damn you, I say!" Then seeming to wake to my presence, driving at me half a dozen vehement questions without stop: "Have you ever had one near you who was a persecution, a perpetual filch, a damned lazy 
scoundrel-full of pretense, hypocrisy, lies, sneakiness? A hog, a poison, a snake, a dog, a beast? A person who defies honor? A man (can I call him a man?) - a man who never comes with a direct question but always with an innuendo? A man who trades on your anxieties, preys upon your good nature, whose presence is a loitering, whose whole life is hollow to all high and excellent purpose? There's such a one here," clapping the letter passionately. "He writes and writes and writes: begs, begs, begs: does not threaten, but would if he dared: something comes every two or three days, and I send something-always from two to ten dollars-and send willingly, sure enough. God knows it's not the money that vexes, worries, storms me! But that such a dog has a hold upon me. The misfortune of the case is, that he happens to be married to my sister. You know the Mrs. Heyde, at Burlington, Vermont. Do you know what it is to stand in such a relationship?" I knew about Heyde: he is a perpetual worry and pain to W. Often I come to W. at night and he tells me, "Dismal news by letter today," which, when I probe, I find to be another letter from this scoundrel, full of poverty and despair and devilish indirections. W. thinks, "If I send nothing, then what of the sister? Perhaps suffering - what-not." And he sends to her, as I understand him; in sending can sense that this fellow reaps benefit, which W. is helpless to prevent. That was the burden of his talk now. I mentioned Samuel Johnson's brother as an allied case, but W. passionately shook his head. "But that is a brother! I can see how it should be with a brother: a brother has big claims. Claims? God! I think all have their claims! But here is a man, arch in hypocrisy, double-dealing, a scaramouch of the worst sort, nowise related to me, who is a constant spear in my side, who commerces my anxieties, troubles, trials-my brotherly affections-and my sister there, she is not a well woman. And he makes arguments of everything - a man who almost shames me and my gospel of the divinity of evil. I send money cheerfully when I can, but to send it to such purpose! Drink? Yes, I suppose that with other things, but that would be to draw his offense mild, to give only the smallest item!" And so for some time. I never saw him in such a storm of indignation. He looked at me all the time over his spectacles - the letter in his hand-his voice raised; I having little to say. "No," he shook his head, "I suppose they are very rare, cases like this. Thank God they are rare. Humanity is way way way above all that, even in its average." And suddenly he folded the letter, put in envelope, said to me quietly, as if restored, "But no, Horace: I must not let this work on me. I have not been feeling extra well today anyhow, and this will not better me." I turned conversation to the paper (Bazar) he had in his lap. He crossed the line by easy transition and soon was in the friendliest mood of reminiscence. "I want to predict about the Illustrated American -it cannot last at 25 cents a week -25 cents is too much. I think I surround all the arguments for keeping prices up-realize them all-then I say, it is no use, it is a fatal position. There is no use resisting the tendency to cheapen things, to democratize literature. It will be democratized." He laughed with the critic who had said, "Ruskin wrote for the people at a guinea a volume." "That is an exquisite satire. I know nothing better. It reaches the heart of the matter. Why," he added, "I always went in my early days to the 25-cent place in the theatre, and it was my breath of life, what I got there, however cheaply secured. What opportunities were tallied! 
What gates opened! I suppose you did so-do so-too. Yes, and all you say about that"-I had spoken of abandon, ease-"it is true. I, too, used to meet and make new friends in the galleries. Often we would go in parties. We heard the best plays, operas, in that way. My early life especially was full of it. I suppose the average man doesn't object to high prices because he only wants to go to the theatre about twice a year. I suppose that satisfies him, but for the wanderers, for the Bohemians we are-many, many times are not too many. The time came when I was on the papers, when I had a pass, by which means I fell literally from my high estate-from gallery to parquet, and it was a fall-I felt it to be such. It was comfortable to have the seat reserved. I admit that, but something was lost - the greatest something. Besides, it was at the top I heard best-got the great distance, effect-ensemble most impressive." I told him stories of my own experience and I evidenced his interest by his questions, which were many.

Some new man has been doubting W.'s humor. He laughed, "He has good backing, however, for full 50 per cent, even of my friends, have their doubts in the same matter." I told him of people who had asked me if W. ever laughed himself-could appreciate a joke. Had they heard his laugh at this they would have been convinced. "That is very funny. My intimate friends would have their best fun with a man who brought them such a doubt!" . . .

\section{Saturday, September 13, 1890}

5:10 P.M. . . . Had got from Harned "The Kreutzer Sonata" and North American Review - they both lay at his feet. He said enthusiastically-I have not for long known him so possessed by a book: "I have read 'The Kreutzer Sonata'-read it today-and it's a masterpiece-as great a masterpiece as 'Othello,' by as great a master. I don't know but greater than 'Othello'-certainly more fitted to the intricacies of modern life-to our special problems." He gave me a sketch of the story: "It is a story of jealousy, of passion, not attended by quite as horrible circumstances as Othello. I think Tolstoi goes over the strong part very easily-does not make much of it, but it is probable enough-more probable than Shakespeare's often are. Oh! it is a great book-a work of art-filed down-thought out-greater than all the Longfellows, all the Tennysons of this age, any age. I confess the book has taken a strong hold of me-it has opened my eyes, made me feel that we have a master with us - a master as great as any. I know of no one who writes in English as he writes, or has ever so written: with such power, such nature, such absence of calculations. I feel that it is a picture of high life-a touch at the heart of so-called society - true in vein, in throb, in all colors and scenes. I am quite disposed to endorse it, too, for often it has come to me, the brutishness of the Orientalism, that gives man any monopoly he chooses with woman-that excites in him such a passion, frenzy, of monopoly, as breaks and wrecks her best sympathies and hopes. As to the indecency, I am astonished that even the blatherskites who attempted to suppress it should see it in that light: it is incredible, it is stupid, foolish to the last degree. If the book is as I read it in a translation where something certainly is lost, what must it not be in its original tongue?" I asked him if he remembered "Sebastopol." "Yes, that was great, 
but this is greater. This is more complete, more intense, more rich." And again: "I do not see that Tolstoi goes much into assertions of his own doctrines. Here and there comes a paragraph in which he vehemently says something, but in the main the story is like a medical treatise: it is physiological, philosophical. It presents a picture faithfully, majestically, masterfully - and he does not spare the picture: he has his surgeon's knife-and he cuts where cutting should be-he binds, he does his work. It is not a parlor-not a titillation of the senses: it is the great gorge, the canyon, the pass, we meet in the Rockies: it is the sea in its play: it is element and element. Those who go to it expecting sweets will be shocked, will fear, will shrink back to their luxuries. I read Ingersoll's piece about the book, and I do not agree with it on the whole, though some of the flights are as true, profound, superb, as at his best. His indirections - most all of them - very great, very rich, full of color. But he does not do Tolstoi justice on the whole. If I found it in my line, I should write out all I have been telling you-put it in print somewhere. But in the first place it is not in my line. Then, I am too lazy. But if there should be any occasion when it may seem in point, I give you permission to use it all-to put the emphasis you know I feel. If I were in easy hail of him I should write it all down anyhow and let him know it from me: but I cannot-it is out of the question." Further: "I must read the book again-see if all this enthusiasm is repeatedconfirmed-as Emerson always did." Referring to the attempted suppression: "It is but another breath of 'protection.' It is in accord with the fact that our globe is now circling in a region where every rod of air or sea or land demands or is given 'protection.' Yes, this despite Blaine's 'reciprocity.' Reciprocity has some little hope-some promise: perhaps may still be the egg from which all is hatched." And still again: "All the masters are not in the past: here is one as great as any. A man whom even Tennyson can't approach. Whose vigor, like the rock, has vast elemental bases: yet has freedom, too-as the flowing together of streams. It has been a revelation to me and an explanation, too, of the world's scorn of him. O, if only William O'Connor were alive! How he would take up a lance for him! And he would say that Tolstoi's picture was true, too, for William knew all those things well-had as keen an eye as ever opened for just such revelations, such frank, bare, sublimely faithful, revelations!”...

\section{Wednesday, September 17, 1890}

7:25 P.M. . . . “I remember Standish O’Grady's piece-it turned up for me today again: 'Walt Whitman the Poet of Joy,' I think. I want you to read it. It is worth while if you have not done so. O'Grady is foreign-Irish - though he writes under the name of Arthur Clive. One of his great points is that Walt Whitman, though the poet of democracy, is received, can be received, only by the cultured few, an inner circle: that the masses can never be expected to compass him. But I know, I see better than that the measure, capacity (if it has any at all) of 'Leaves of Grass.' O'Grady brings back to me Stedman's great point years ago, that I had snubbed the collegiate, the universitarian, the cultured influences, whatever, in profession for the etat major: had put him-it-them-into unjust background. But he has not urged that now for 
some years. It occurs to me, to ask if he has abandoned it?" Did he think a literary man, say of the distinctive character of Stedman, could see the fullness of "Leaves of Grass"? "No, I do not. Stedman is himself the college man: by his post, his surroundings - we might almost say his tendencies. But Stedman is one of the beautiful happy specimens too: an open, enthusiastic, responsive nature first and last. But Stedman is like the rest: he pounces upon a trope-a line, some measure, the method and habit of a verse-makes too much of that as, indeed, do nearly all the fellows. Perhaps Bucke is the only one of the whole body who does not give the least deference to that. It is a significant fact in all that clusters about our attitude." And he further said, "No, Stedman is wrong about America, though there are Americans whose affection and loyalty are vehement, fiery, almost savage. And that will be a truth to know with other truths." I quoted to W. Bucke's remark that he had suspected sometimes that Gilchrist's admiration was “only skin deep." W. said, “I don't agree with the Doctor. I would not place the matter in that shape at all. So far as appears to me, Herbert's affection, sympathy, adherence, is a quality that lasts out of honest genuineness." Then after a pause, "And that brings me again to the danger existing in misunderstood words, thoughts, persons: the infinite stretch of misjudgment - often falsehood - the wide reach and distance between people who ought to know, to love, one another." I went over and sat on a chair near him: he put his hand on the edge of the chair, indexing me. "I can illustrate it. There is an engineer in Camden here named Pine. Warrie knows him; met him the other night, again. It seems Pine knows me-I do not know him. Warrie said something to him about me, whereat Pine laughed, by and by saying, that now Warrie had said what he had and he (Pine) had laughed, the laugh ought perhaps to be explained. He explained, 'I suppose you think it queer that I laughed?' And Warrie replied, 'Yes, damned queer!' Pine going afterward into particulars, to say that whenever anyone spoke of Walt Whitman and his conveyance it made him laugh to remember what his dear mother" $-\mathrm{Oh}$ ! the tenderness W. put into that phrase, as he repeated it- "Yes! What his dear mother had told him: that every time she saw Walt Whitman wheeled past in his chair she had an almost irresistable impulse to rush out of the house and pitch him, chair, man and nurse, into the street, as humbug-one of the greatest humbugs on earth. Now Horace, what do you think was at the bottom of this? Nothing but a lie, a damned lying lie, but a damned uncomfortable lie, too: a lie like this: that I had said to someone Mrs. Pine knew, 'Women? What are women anyway? Are they anything more than a lot of old cows?' Think of it: think of that as a reflection of my work, of my life, of my own dear, dear mother! Yet this good woman hears it, has the proud womanly motherly resentfulness of its hate, its injustice! I loved it in the dear woman, but hated the damned irresponsible lie! And that shows the imminence of this spirit of lies: how, often we seem surrounded by it, made its victims, how, often, we seem beyond having protection in our innocence." . . .

\section{Tuesday, October 21, 1890}

[This is the evening of Robert G. Ingersoll's lecture-benefit for Whitman.] . . . So to Philadelphia-reaching Hall at about 7:15. Some people al- 
ready in seats. Baker and Morris flitting about-as, indeed, I was at once. By and by Williamson was pointed out as waiting for me-a good face, sandybearded, rather pale. Very cordial. We talked freely together. We had retained seats for Ingersoll's family in the fourth row. The audience came-quite a large number of admissions. The stage people came. Here were some of them: Mrs. K. S. Traubel, Bucke, Harned, Johnston, Mrs. Johnston, Mrs. Harned, Anne Montgomerie, J. K. Mitchell, Agnes V. Traubel, Horace L. Traubel, Morris Lychenheim, Jacob Lychenheim, J. H. Clifford wife and Charlotte, David McKay and wife, J. D. Law and wife, Geoffrey Buckwalter, H. L. Bonsall, Cabel Edelheim and daughter, Frank Williams, Harrison D. Morris, William Ingram, William Ingram, Jr. Most of these and others assembled in the wings. W. was driven up to the front door about 7:45, he was taken in by his chair through the banqueting room, helped up the three flights of stairs to stage by Warren. Ingersoll came along shortly after. Interesting little colloquies in groups - congratulations to W. W., to Ingersoll, to W. by Ingersoll, to Ingersoll by W. - We had many peculiar and happy greetings. Finally came the going on the stage. Bucke was urged to start-went on alone-was clapped and cheered, as I know, for Walt Whitman. After others had followed and we were pretty well settled, W. was wheeled on by Warren and set at the center of the stage. In a few minutes more Ingersoll stepped forth-put his matter on the reading desk, picked it up again, stepped free of obstruction and launched to his speech, without preliminary. Baker had given me one of the Ingersoll printed copies - "the first copy" he told me-in the forenoon: and in finding that Ingersoll had forgotten to bring one over for himself asked it back. Ingersoll had taken this-cut the margin close to the printed line-now held it in his hand and read. Whitman seemed very pale. I was surprised at his loss of color. Ingersoll spoke upwards of an hour and three quarters. I have known him to speak with more dash - never with more absolute force and eloquence. His superb rendering of some of the poems captivated heart and mind. "The interrogating thumb" episode, the Paumanok picture, the Lincoln poem, whether in rendering or epitome, were gorgeous in integrity and feeling, sense and utterance. I noticed as he went on W. appeared moved in extraordinary ways - his paleness increasing. Ingersoll evidently considered the gravity of the occasion. He had written as he spoke, for the world which could not share this hour as well as for the fortunate individuals who could. The melody of his voice, his noble mien, his pathos and reserve-impressed and inspired. W. interpreted it all into its consistent heart-speech. By and by he concluded-a master touch on an instrument of grand and delicate compass - retiring to a seat next Whitman-but as the audience rose to go, he rose quickly again - threw his voice ringingly out-saying that W. had something to say and they should wait to hear it. W. was then pushed a couple of feet forward and spoke. For an instant - for more than an instant-I feared he would utterly collapse. The little speech he had printed-the eight short lines-were played with, stumbled over-not lamentably (because he gave sense to their utterance in the end) but to our trepidation. Then all was done. His voice was not strong, but had a noble pathos, vibrant and penetrating. Then the audience dispersed, slowly-such of it as did not come on the stage, to congratulate him or Ingersoll-or both. Ingersoll had listened and looked with grave solicitude as 
W.'s difficulty was evident, but had kindness and grace in every word and act. W. gave me slips containing his speech thus: "After all, my friends, the main factors being the curious testimony called personal presence and face to face meeting, I have come here to be among you and show myself, and thank you with my living voice for coming, and Robert Ingersoll for speaking. And so with such brief testimony of showing myself, and such good will and gratitude, I bid you "hail and farewell." "W. had said to me this afternoon, "I had a letter from the Colonel today: he closed by saying, 'And now, may the Lord love you - but not too soon.' It was sweet, loving - took me irresistibly back to my dear father. It was so like him. Now as Ingersoll stood by W. he said, "As I told you in the letter-may the Lord love you, but not too soon." W. smiling-receiving congratulations on all hands. Ingersoll introduced his wife and daughters - W. saying, "Ah! girls! I have heard so much about you, I have long wished this chance to take you by the hand!' The 'boys' were loth to adjourn abruptly. Arrangements were made to go up to the Lafayette-a few of us-for a talk. I whispered to W., "Don't you think you could take a little to set you up?" He laughed and responded, "Yes-anything! anything!" $\mathrm{He}$ consented to go with us. Ingersoll would be there and share the improvised hour. W. was helped out of the Hall and into his carriage-was driven up the street. Though laborously, he went valiantly. The walking troubled him somewhat, but he persevered. He stayed with us at the Lafayette till 11:40-sat at table (Ingersoll by and by coming downstairs from his people)-debated, told stories. He at one point took Murger's poem from his pocket-reciting it with gusto-was much applauded. He and Ingersoll had a good deal of discussion-about Christianity, Deity, immortality, etc. At one point W. said, "Oh, Robert! Robert! sometimes I think there is a great gap between us-between our thought, then again I wonder if there is any at all!" Bucke exclaimed, "Not an inch's difference! not an inch!" Then at another point W., after his emphatic "No! No!" to Ingersoll's vehement talk-W. suddenly seized his hand in both of his own and cried, "But Robert, in your fight against that-in all the main lines of your great work-I am with you, I second you, I endorse you, I wish to thank you!" Ingersoll was of course strong, but W. several times aptly and sufficiently answered him. But as a rule Ingersoll cannot-could not then-be coped with. When Ingersoll thanked W. for the human trend of his work, W. expostulated, "But I, too, Robert, go among the clouds!" Quick as lightning Ingersoll retorted, "Yes, but you take a devil of a lot of dirt with you!" It was a brilliant play of wit and eloquence. The fellows gradually drew up to the head of the table-the waiters (they looked Irish: probably Catholic) looked as aghast at Ingersoll's daring speeches. Ingersoll said at one point that Robert Burns was a thousand times more to him than any founder of religions, etc. It is not possible to reproduce this great hour. Among those present were Harned and wife, Clifford, Bucke, Morris, Williams, Williamson, Johnston and wife, Buckwalter, Baker, Ingram, Warren, Mrs. Davis. W. was very cordial when I introduced Baker, who came in late after a settlement with Campbell. Baker gave me the "pot" - a bundle of bills - a giant fist. Johnston rose and congratulated the party: here was a thousand dollars, etc.! The party hurrahed. Baker wished to go off with me to settle finally. Arranged to do so after the party dispersed. W. cried out to me at one point, as 
he saw me strutting about the room with the bundle under my arm. "Hadn't you better give me that, Horace?" I laughed, refused, "Not yet-not till we know just how much of it is yours!" At which he laughed himself. After further talk, Ingersoll himself arose-offered to go-which was a signal for all hands. W. was helped out to his carriage-I stayed to work with Baker. Baker wished to ask some questions of Ingersoll, who had already gone upstairs - we therefore following. Ingersoll already partly undressed, but he came to his room door-talked. Would not let us take out for any of his own expenses-not a penny-saying, "I'm sorry it's no more"-Baker had told him about what it was-"but as it is it's a little purse for the old man!" Then he very cordially gave us good night. We going thence to Green's and to Baker's room-making final settlements - finding a surplus (net) for W. of $\$ 869.45$. Baker and Ingersoll acted nobly - with heart and brain-conferring all "on the old man." I felt the depression of the hour as I sat there to count the money after the eloquence, the wit, the presences, of those earlier three or four hours. But there was compensatory elevation in the noble demeanor of this great man's great clerk. Later-on towards one o'clock-I bade Baker good-bye: it was with emotion! I had gathered a real love for this good man. If spirituality had voice and gesture through the whole transaction of this fortnight-these were the exhibitors. That night I had their gift under my pillow - that gift, freighted with comradeship, humanity, high moral impulse and possession.

Ingersoll (while at the Lafayette) broke a cracker on the table with his forefinger - "The chick is born-walks off with a bit of shell on its back. I believe in the God that inhabits the egg." And yet they would call him atheist - with a belief altogether Emersonian except for its terminology!

\section{Sunday, November 23, 1890}

5:20 P.M. W. just finished eating dinner. Reading paper in the dim twilight. Looked well in color (as always post-dinner) but said of his condition, "It is only so-so. I pull through - that's about all." I put in, "You are the best man I know for 'pulling through' things," which excited his laughter. "I keep my troubles on a field I can control," he said, jokingly, "remembering the doctor who, called in to see a patient, said, 'Madam, if only I could shift this thing to fever, I'd cure you. I don't know what's the matter with you now, but I'm hell on fever!' " And then, "As long as I can keep it fever, Horace, I'll be all right!" Referred to papers he had read today: "They appear to be full of the Parnell matter, which of course I did not read. There are two things in the papers nowadays which I skip every time: the Parnell and Stanley columns. I take little interest in either. But I see the venom with which the papers pressure Parnell. The Record had an editorial this morning saying he should go-must go. I read enough of it to see that conclusion."

Said again, commenting on Burroughs' idea that W.'s late work lacked in the poetic, "So does it all, that was one of the hardest jobs in my early life - to get the poetry out: but I did it," laughing. . . . 
3:10 P.M. Met Coit at Broad Street Station-with him across river and to Whitman's this hour. W. at first seemed disposed to say nothing or very, very little, but by and by a well-turned question from Coit drew him out into fine communication. He had just been out in his chair, he said, but spoke of his lameness - that he was "much broken-up" and "whacked away splinter by splinter," etc. Coit alluded to John Burns. Had W. met him? "No-but I have had letters from him-several." Coit knew him well, going into some particulars and W. listening and questioning intently. Did W. take interest in the labor question? "Yes, some. but it is not intense, not absorbing. I might say I have not time for it." Had he ever been to Europe? "No-I am quite a fresh-water fish-quite. Time was, when I was young-years, years ago-that I aspired to go to Europe-indeed, to go round the whole world. But that desire-its expectation-is all past now." Coit admitted that when he went to Europe a few years ago he knew (cared) nothing of Whitman - that his associations with radical enthusiasts there had won him over. This I could see pleased W. Coit also spoke of the frequent pictures of W. in Townbee Hall. This was new to us both. Talk, however, lapsed sadly till Coit struck upon America-what it was as a unity: whether its states did not foster division-destroy national idealism. There was Westminster Abbey-he had seen the funeral of Browning there. And for America, why not an Abbey or Pantheon, too? But W. shook his head. "No, I do not believe in them. I do not think we want Abbeys or Pantheons. That is the idea of concentration." $\mathrm{He}$ spoke very deliberately. "America ought to be diffusion-ought to scatter. Nature's method is always the method of diffusion -in her winds, skies, streams, all. I can see how the Abbeys might be all right-necessary-for England, for Europe, but ours is a different necessity." But was not a central idea, a purpose, better enforced in such a unity as England, which knew no states? etc. But W. demurred: "America-her clouds, her rivers, her woods - all her origin, purpose, ideals; let it be reflected in the majesty of each individual. Nature exhales, let man exhale-let our America exhale-to do this is her work." But Coit missed the sense of fatherland here, etc.; felt the lack of a grand national ideal. W. assenting, "I can see all that. I am duly taking account of all you urge-yes, acknowledge it. Yet I know it is a thing we will overcome-that our future is ahead of all that." He felt that "the majesty of life, being-let it be reflected in every mechanic, laborer, lawyer, statesman, artist, everyone." Coit asked about W.'s feeling for Browning and he said, "I feel he is a great light - yet I really know little about him-not enough to speak upon." This was the drift of the talk. The simple naturalness of W. never more beautifully set forth. Coit remarked it instantly on our exit. Told W. frankly he had been the first to give him the sense of America as a unit, etc.

I told W. what J. K. Mitchell had written me about the pills. "Oh yes! but I am taking them-and taking four or five a day. I think that is what he directed-and that reminds me I will take one now: it is about time," looking for the box on table and simply and naturally opening and providing himself. 
5:10 P.M. In his darkened room, his dinner done, W. was restfully dreaming an hour's vision towards the Northwest. Our talk was to me a happy one. He seemed free and unconstrained. He had read the proof of Kennedy's piece? "Yes - it is in the envelope there," pointing to the table-"You may take it with you when you go. I like it very much for its kind; it is certainly the best piece I know-certainly the best thing Sloane has done. And it would seem about time something was done in the direction of the recognition of the women: for some of us to dwell upon the lives of the noble big women. History teems with accounts of big men-genius, talent-of the he-critters, but the women go unmentioned. Yet how much they deserve! I know from time to time there are spasms of virtue-some fellow sets up to describe the salons-as in one of the magazines lately"-Century-"but what is that? I have no admiration for the formal elegant lives of salons. I have in mind the noble plain women I have met-many of them-women to whom the word 'literature' even is unknown; mothers of families-mistresses of households-out over the country-on farms, in the villages: marvelous managers-tender, wise, pure, high - the salt of our civilization. I have often resolved to write this up myself, but am stayed: that would spoil it all to write it up! - and so have not done it."

Stedman had thought Bucke "a lunatic" from his radical endorsement of W. There was one instance of Bucke's reference to W.'s "pink-white skin"-making much of it. Stedman saw that had "excited the laughter of the literary fellows in New York." W. exclaimed, "And that is a compliment: I regard that as a plume in his honor. Why should he not? What are we here for? It is as natural for these fellows to antagonize as for us to be: they must in the very nature of things. As to the color of the skin - that was not really new to Doctor, though he adopted it. Conway was once with me-I think on the Long Island Shore: we went bathing together: and he remarked the peculiarity in one of his English articles. Of course, I know that wouldn't soften the charge if a charge belonged anywhere. But it is a pure argument, anyway, and I am surprised that a cute man like Stedman, any cute man in fact, should attach the least importance to it. I have told you about one of my meetings with Beecher? He declared once-in a company-I was one of them-that he did not know one drunk from another-boasted of it. I think-thought at the time-that the fling was at me. But though it excited an inward retort, I said nothing-held my peace. But what I thought was this: that it was very much as if a doctor would boast-'I know nothing of your guts, blood, excrement, wounds, sores - it is all unelegant, forbidding, nauseous, to me: I am the doctor of your proprieties'-very much that way: for what have we but to look for just those things? - not, it is true, to forget the daintinesses, in their places, but to have an elemental authority, taking all as part of fact and history. And all this leads to what I was going to say about Doctor. Stedman should know me, know 'Leaves of Grass,' well enough to see that we look to reflect, to stand for, fact. Not pleasant fact only, but fact: and fact means all tempests, horrors, hoggishnesses-everything-whatever! I am always curious in just such points-complexion, the color of a man's hair, eyes, voice, legs, arms, trunk, foot-all that goes to make him himself. And Doctor has but seen for himself 
what I have seen for myself. It is our method." As to the "halo" O'Connor declared to Stedman he had seen about W.'s head, W. would say nothing except to remark, "it is new to me, entirely new." . . .

\section{Monday, February 9, 1891}

6:00 P.M. . . . He had read Julian Hawthorne's article on Heywood (in Twentieth Century). "I enjoyed it a good deal: Julian's heart is in the right place. The only thing I know against his chance is that he is in New York-and that atmosphere!" I interrupted to say, "But he is not-he lives at Sag Harbor-seems to be altogether a fresh out-of-doors man." W. replying, "I know Sag Harbor-have been there: it is on the extreme end of Long Island, right in the point of the angle of the fork"-indicating with his fingers. "It is not a desolate place-is quite a town-has several dozen stores. No doubt Julian is a healthy fellow, and as we know, from best stock-brains, body. His daughter, who was here-came with Stoddart-was herself a fine specimen-unconventional-tall as I am-kissed me warmly, as all the unconventional girls do." Laughing - "Even her dress was plain." And, "Certainly, Julian's protest for Heywood is manly and ought to create a change." Several places Hawthorne had coupled allusions to W. and Ingersoll. W. said: "Yes - that is right. I do not object in the least. In the letters there you will see the first Symonds note to Johnston-the copy. Poor Symonds! But do you know, Horace, I consider the friendship of men like Symonds and Ingersoll a great plume in our cap-great. Symonds is the quintessence of culture: he is the culture of culture of culture-the essence of an essence. And Bob-I might say he represents the doctrine-if I may speak of it that way-of 'One world at a time.' Men and women, sense, love-all in a majestic high sense, too. If I had any difference with him at all, it would be at this point. 'Leaves of Grass' would say, the stamp has been put on these things for something deeper yet-for something yet to come. If there is any lesson nestling down, down-it is that." We spoke of health in connection with 'Leaves of Grass.' I said, 'It fortifies us with cheer whatever may come." He replied: "That sets the standard very high - that requires a long leap-the bars are up-up"-looking at me-I responding, "I know it, but a man who knows 'Leaves of Grass' is prepared to take the leap." Passed to another subject. What did he think of gorgeous architecture-high luxurious living - as an aesthetic inspiration to the masses? He laughed but said, "I can see why it should be urged-it is a legitimate argument. I think even Emerson held it to some extent-used to put it beautifully - that even royalty, even the kings, aided in the process by which civilization gained its dignity. It is a subject admitting of two sides: it is like the question of Christianity - the doubt often comes to me, as they say it did to Elias Hicks, whether it has not done more harm than good in the world. I have never been quite prepared to answer that. Sometimes I have thought this - that nothing is more to the credit of the human critter than that it crept to Christianity, adopted it, used it, climbed it over and over, possessed it with that instinct, so wonderful in the vine, which crawls, crawls, crawls along the ground as if it knew that nearby was a post which it must make its own." I said, "That is the right order of the process: but the average Christian will have it 
that the post crept towards the vine!" W. laughed very heartily. "Well said: but what have we to do with what the damned parsons have to say-the Methodists, Baptists, Presbyterians, pleading their cases?" I questioned, "And you think the vine will by and by pass on, to possess other posts?"- "Oh! boy! I do-I do! - that is evolution: and 'Leaves of Grass' and evolution are one." And again: "We can't know what we are bound to-but bound to something? -we can't doubt it-no, can't." ... .

\section{Thursday, February 12, 1891}

5:30 P.M. Spent good half-hour with W. He sat in the small chair by the fire-his room dark - the light through the half-open stove-door playing with his beard and hair, and casting shadows on the wall. W. continues to complain of his condition. "This is a bad period with me," he said. "Something is working, working-who knows for what?" . . . Hailing when I came. He had "enjoyed the sound." Had held my hand in his some time-"to feel its out-of-door cheer, vigor: it has the warmth, smell, of the fresh air-a healthy cold." We talked of General Sherman, at death's door. The papers full of it this morning. John Sherman telegraphed the President the General was enough better to warrant a faint hope of his recovery. W. listened as I recited this - then spoke at some length of the General: "I don't think I ever had a talk with him-came face to face with him that way-but I have met him. He was a warrior-Normanesque, I was going to say: he seemed to me like a Norman baron, lord of many acres - with adherents, servitors-all that-something of grandeur, hauteur, haughtiness. That was the man. I think I have told you a story about him-I shall tell it again. . . . It was in the review of the troops after the war-in Washington-I can see the day, the long, winding, noble procession-the sky, people, earth. Sherman was at the end of the line-rode, uniformed, a noble animal. Kept a distance of perhaps 15 feet between his own place and the file of aids. These aids spread entirely across Pennsylvania Avenue-all mounted. In front of Welland's a woman set forth from the crowd-straight up to the General's horse-gave him a bunch of flowers. It all comes back to me-vivid-powerful-the etched features of the scene: he took the flowers, curtsied, put them - an instant only - to his nose - then held them out and back with his hand, so"-indicating-"for the instant I did not know what it meant, but before I needed to ask, one of the aids galloped out of the line, up to the general, took the flowers from him, returned to his place again. What could better present the man than that? No-no-Grant was quite another man. Even that day, where was he? Off in his corner-in his place, no doubt-but making nothing of it, at most. Probably going by some obscure way to rejoin them later on. Out of all the hubbub of the war, Lincoln and Grant emerge, the towering majestic figures. There were others: Seward, Sumner, Phillips-such-elegant, refined, scholarly - the gift of colleges, the past, book-keen, great men: these: then, by contrast, Lincoln, Grant! Don't that tell everything?" Dwelt upon Grant's plainness. "Grant savored of our soil-was Saxon-Sherman Norman. Grant hated show-liked to leave things unsaid, undone-liked to defy convention by going a simple way, his own." . . . 
At 328 at 8:15 A.M. W. had been through an ordinary restless night. Warren just turning him to right. Was the very picture of death-eyes closed, color gone, hand thin. Warren proposed to turn pillows. He objected. Yet usually welcomes it. Says nothing save monosyllables-seems to have no strength. Our conversation will illustrate his weakness-I stood in doorway. $\mathrm{He}$ saw me (his eyes spying me after Warren had turned him).

"Horace" - a struggle, a cough.

"Yes-me."

I advanced. His hand lay on the chair pillow. He opened it, my hand dropping to its clasp, which was weak.

"Morning."

"Morning-and a fine morning too-after a cold night."

"Cold?"

"Yes."

Then after silence-"How was your sleep?"

"Middling."

After a pause.

"News?"

"Nothing-nothing for us."

"Arthur?"

"I haven't heard from him yet-but expect to."

"Hope so."

This reference to Stedman shows how closely he thinks up and in affairs. I asked again-

"Have you had a look at the Telegram?"

"What?"

"At the Telegram."

"Yes."

"Was it right?"

"Very-good."

"Do you feel any return of strength?"

"None-none."

"Loss?"

"Always-more-more."

"I am on my way to work - to the busy desk there in the big town."

"Luck!"

"I tire of it at times."

"No doubt."

"But I stick to it."

He smiled-"I know you do."

Warren had left the room. I reached over-kissed his hand.

"Good-bye-good-bye-Walt."

His face lighted up-"Bye-bye."

"I am sorry you must suffer so."

"It's-right." 
Every word a struggle-and again I kissed him-and heard him say-"Bless-bless." Coughed-choked-breathed heavily. I turned as I reached the door. His eyes opened. He smiled. That smile! And after I had gone I had yet to go back. Again to see him, to have his smile. In next room Warren. I stopped to say a word. Then W.'s bell rang-Warren hurrying to W. at once.

"Will you go over left again, Mr. Whitman?"

"Yes."

And was turned without speech on other side. Warren said to him - "When you turn next I will try to wash you a little and give you your breakfast and get you in shape for the doctors when they come." $\mathrm{He}$ only answered "oh!" and closed his eyes.

\section{Monday, March 21, 1892}

6:18 P.M. W. just being turned to left-and I went quickly in-he seeing and instantly calling my name-Mrs. Davis retiring. I sat on edge of the bed and we talked for full 20 minutes. When I asked him - "How have you passed today?" he answered-"It has been a dreadful day: I suffer all the time: I have no relief, no escape: it is monotony-monotony-monotony-in pain!" Yet not uttered complainingly at all. Coughed violently-choking a good deal: and the constant rattling of mucous in the throat. His words throughout our talk uttered feebly - brokenly - but the sentences and thought coherent and clear as twenty years gone. Hand cold-forehead warm. He pressed my hand again and again while I stayed. I read him Rossetti's letter. He called it "very remarkable-very sweet, too" - and then added-"I am happy to know he got the book." "They are all acknowledged now." "So? And you sent Joe Gilder's?" "Long ago." "No-I meant the copy for Roger Riordon." "Oh! that was mailed yesterday." "Good, good!" And I read him Kennedy's letter. He felt moved to hear this too. "The good Baxter, too." And then - "Rossetti has been a long and faithful friend-has been loyal from the first. And he says he has read the entire book through once more? It is a tribute-a good deed. Things seem to have taken a turn for us-eh? Horace? Do you think?" And after a pause-"Any more letters?" - at which I read him William Clarke's, sent by Johnston. "Who is he?"-when I was done. "I don't quite remember him." And yet at the close- "I remember the printers - that was a famous time we had-but Clarke? No-no. You say he is an able fellow? I suppose, I suppose. England is sending up these days some as good specimens-young men, firm, big, royal in everything - as ever stalk into history. We have known more than a few-and there must be many more than we know." Several times choking painfully and some of his words only whispered. What of Nellie O'Connor? "There's a color of mystery about her silence, Horace. You say you haven't heard from her in eight weeks?"-and he advised "Write-write until you hear." Miss Porter wished to print the Whitman-Ingersoll letters. Should I let her? "Yes-if you wish: do it. But if you do, get me a proof-let me see how they show up in the type." "But you don't make a point of having them printed just now?"- "Oh no! I leave the when in your hands." Then I asked-"What do you think of another piece from me on Whitman-Lowell?" "Do you mean 
it?" "They will print it: Miss Porter has written me." He was silent a bit - "Do you have any real intentions?"-ending in that curious way. "Yes-some. Do you see any reason against it?" "None at all-on the contrary I can see reasons why you might wish to go on-yes, in several directions." "I am glad." "But keep the reins in your hands! Though I hardly need warn you that." I was silent-looking out the northern window, in deep thought. Suddenly his voice rose, quite firm and easy again, for a minute at the start, then relapsing into the disastrous struggle now becoming his norm. "Horace," he said, "if I wrote anything more I would compare Tennyson, Whittier, and me, dwelling quite a bit on the three ways we each have treated the death subject: Tennyson, in 'Crossing the Bar,' Whittier in 'Driftwood'-both ecclesiastical, theoretical-and my 'Good-bye, My Fancy'-based, absorbed in, the natural. That that I've just said is quite a significant"-here he broke off from vain effort to say more. I had whipped a pencil out of my pocket and written as he spoke-he seeing me and nodding assent. I commented-"That is perfect in itself: one needs hardly to say more: people may find the rest for themselves." He first responded-"True-true-perhaps," and then-"But it will bear saying in full: it tells the whole story of 'Leaves of Grass.' " I saw him getting very weak - "The girls have gone to Boston-I will write them." "Yes-give them my love." "And now good night, Walt-you are wearied out." "It is easy for me to get so: there's nothing to me any more"-and he added-"I have had several foreign letters-Warren read them to me-but I hardly know who from. Good fellows, all!" - and as he pressed my hand he said slowly, "Good night." ... 